\title{
Utilization of Bamboo Biochar and Phonska Fertilizer on Cultivation of Maize (Zea mays L.)
}

\author{
Petrus Malo Ngongo ${ }^{1}$, Yohanes Parlindungan Situmeang ${ }^{2}$, Luh Kartini ${ }^{3}$ \\ 1. Alumnus of Agriculture Faculty, Warmadewa University, Denpasar-Bali, Indonesia. \\ 2,3. Agriculture Faculty, Warmadewa University, Denpasar-Bali, Indonesia
}

\begin{abstract}
This study aims to investigate the effect of biochar and phonska as well as its interaction on the growth and yield of corn crops. This experiment used a randomized block design (RBD), a factorial pattern with 2 factors. The first

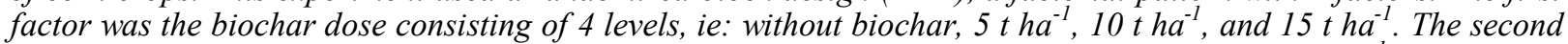
factor was the dose of phonska fertilizer consisting of 2 levels: without phonska and $300 \mathrm{~kg} \mathrm{ha}^{-1}$. The results showed that the dose of biochar $10 \mathrm{th} \mathrm{h}^{-1}$ gave the highest dry weight of seed per hectare of 8.12 tons, an increase of $32.77 \%$ compared with without biochar of 6.12 tons. The treatment of phonska fertilizer dosage of $300 \mathrm{~kg} \mathrm{ha}^{-1}$ gave the highest dry weight of seed per hectare of 8.07 tons and the increase of $26.68 \%$ compared with without phonska of 6.37 tons. Based on a result of regression analysis test obtained optimum dose 10.44 tha $a^{-1}$ with a dry weight of seed per ha maximum 7.90 ton.
\end{abstract}

Keywords: charcoal, bamboo biochar, NPK phonska, corn.

Author Correspondence:

Yohanes Parlindungan Situmeang

${ }^{2}$ Agriculture Faculty, Warmadewa University, Denpasar-Bali, Indonesia

E-mail: ypsitumeang63@gmail.com

\section{Introduction}

Corn (Zea mays L.) has an important role in the fulfillment of food for some people. Corn, as one of the food crops in Indonesia, ranks second after rice. Corn commodities are very supportive if developed in Indonesia which has a large area of land, because corn plants have enough potential to be cultivated and easy to cultivate, even in a relatively short period of area per hybrid corn plant can produce and grow rapidly [1].

Biochar is a fine grain of porous substance when used as a soil enhancer can reduce $\mathrm{CO}_{2}$ from the air. In soil, biochar provides habitat for soil microorganisms, but not consumed and generally applied biochar can stay in the soil for hundreds or thousands of years. In the long run, biochar does not disturb the carbon-nitrogen balance, but it can hold and make water and nutrients more available to plants [2]. Several research results of biochar dosage and NPK fertilizers give various effect on the corn plant. Research result of [3] shows that the utilization of bamboo waste biochar dose of $10 \mathrm{tha}^{-1}$ gives a real effect to the height of the plant and total fresh weight of corn plant. While [4], with a dose of $15 \mathrm{tha}^{-1}$ yielding fresh weight of 100 high corn seeds. Treatment dosage of biochar 5-10 $\mathrm{t} \mathrm{ha}^{-1}$ gives a fresh weight of the best sweet corncob [5]. Biochar dosing of $10 \mathrm{t} \mathrm{ha}^{-1}$ and phonska dose of $300 \mathrm{~kg} \mathrm{ha}^{-1}$ can increase the growth of maize plants [6] and yield of Bisi-2 hybrid corn [7], [8]. The biochar formulation of $10 \mathrm{tha}$ hith compost of $20 \mathrm{tha}$ a and phonska $300 \mathrm{~kg} \mathrm{ha}^{-1}$ gave the 1.01 IBCR (Incremental Benefit Cost Ratio) value which was considered feasible and profitable for corn cultivation [9]. Combination of dosage of biochar $10.52 \mathrm{t} \mathrm{ha}^{-1}$ with compost dose $20.22 \mathrm{t} \mathrm{ha}^{-1}$ and NPK phonska 313.37 
$\mathrm{kg} \mathrm{ha}^{-1}$ give highest value RAE (Relative A gronomics Effectiveness) equal to $113.99 \%$ which is very effective for cultivation maize on dry land [10].

Alternatives used to increase soil productivity are known to have soil physical, chemical, and biological properties that are less favorable for plant growth, phonska fertilizer is needed as a source to add macronutrients N, P, K and S, and other microelements [11]. According to [12] phonska fertilizer contains N (15\%), P (15\%), K (15\%), and S (10\%) that can increase production and quality of harvest, increase plant resistance to pests and diseases, making plants greener, spurring root growth, spurring the formation of flowers, and increase the size of fruit, bulbs, and grains. The use of phonska fertilizer guarantees the availability of nutrients for plants, besides phonska fertilizers combined with biochar, can also increase the effectiveness and efficiency of fertilization.

This study aims to determine the effect of biochar dose and phonska fertilizer and its interaction on growth and yield of corn crops. The hypothesis proposed in this research is the dosing of biochar $10 \mathrm{tha}^{-}$ ${ }^{1}$ and phonska fertilizer $300 \mathrm{~kg} \mathrm{ha}^{-1}$ and the interaction can increase the growth and yield of a corn plant.

\section{Material and Methods}

This research was conducted in Sulahan Village, District of Susut, Bangli Regency with height about $762 \mathrm{~m}$ asl. The materials used in this research are seeds of Bisi-2 hybrid corn, biochar made from bamboo waste, NPK phonska fertilizer (15-15-15), and pesticide (Matador and Confidor 5Wp), while the tools used are hand tractor, hoe, shovels, rakes, machetes, scales, gauges, raffia straps and stationery.

This experiment used a randomized block design (RBD) with a factorial pattern. Treatment consists of two factors: the dose of biochar (B) and phonska fertilizer (P). The first factor, the dose of biochar (B) consists of 4 levels, namely: $0 \mathrm{t} \mathrm{ha}^{-1}$ (B0), $5 \mathrm{t} \mathrm{ha}^{-1}$ (B1), $10 \mathrm{t} \mathrm{ha}^{-1}$ (B2), $15 \mathrm{t} \mathrm{ha}^{-1}$ (B3). The second factor, the dose of phonska fertilizer (P), consists of 2 levels: $0 \mathrm{t} \mathrm{ha}^{-1}(\mathrm{P} 0)$ and $300 \mathrm{~kg} \mathrm{ha}^{-1}(\mathrm{P} 1)$. Thus there were 8 treatment combinations and each treatment was repeated 3 times, so there were 24 plot experiments.

The variables observed in this experiment were plant height, number of leaves per plant, total leaf area per plant, dry weight of 100 seeds per plant, and dry weight of seed per hectare. Data were analyzed statistically by using analysis of variance in accordance with the design used. The treatment was significantly affected by $5 \%$ LSD (least significant difference) test, while to know the optimum dose of the observed treatment was done regression analysis. Data processing is done with the help of Microsoft Excel Program Software, Minitab, and SPSS.

\section{Results and Discussion}

\subsection{Research Results}

The results of statistical analysis of biochar and compost effect on the observed variables and significance of bamboo biochar (B) and phonska fertilizer (P) effect on the observed variables are presented in Table 1. Effect of biochar and phonska on all observed plant variables are presented in Table 2 .

The interaction between biochar $(\mathrm{B})$ and phonska fertilizer $(\mathrm{P})$ had no significant effect $(\mathrm{P} \geq 0.05)$ on all observed variables. Biochar treatment significantly influenced to most observed variables, except on the variable of leaf number per plant had no significant effect $(\mathrm{P} \geq 0.05)$. While treatment of phonska very real effect $(\mathrm{P}<0.01)$ to all observed variables. 
Table 1

The significance of the effect of bamboo biochar dosage $(\mathrm{B})$ and phonska fertilizer $(\mathrm{P})$ and its interaction

$(\mathrm{BxP})$ on growth and yield of the corn crop

\begin{tabular}{|c|c|c|c|}
\hline \multirow{3}{*}{ Variable } & \multicolumn{3}{|l|}{ Treatment } \\
\hline & Bamboo Biochar & Phonska Fertilizer & Interaction \\
\hline & (B) & (P) & $\mathrm{BxP}$ \\
\hline Plant height & $* *$ & $* *$ & ns \\
\hline Number of leaves per plant & ns & $* *$ & ns \\
\hline Total leaf area per plant & * & ** & $\mathrm{ns}$ \\
\hline The dry weight of 100 seeds per plant & $*$ & $* *$ & ns \\
\hline The dry weight of seed per hectare & $* *$ & $* *$ & ns \\
\hline
\end{tabular}

$* *=$ highly significant effect $(\mathrm{P}<0.01) ; *=$ significantly affect $(\mathrm{P}<0.05) ;$ ns $=$ not significant effect $(\mathrm{P} \geq 0.05)$

Table 2

Effect of bamboo biochar and phonska fertilizer on all observed plant variables

\begin{tabular}{|c|c|c|c|c|c|}
\hline Treatment & $\begin{array}{l}\text { Plant } \\
\text { height } \\
(\mathrm{cm})\end{array}$ & $\begin{array}{l}\text { Number } \\
\text { of leaves } \\
\text { (strands) }\end{array}$ & $\begin{array}{l}\text { Total } \\
\text { leaf area } \\
\left(\mathrm{cm}^{2}\right)\end{array}$ & $\begin{array}{l}\text { The dry weight } \\
\text { of } 100 \text { seeds } \\
(\mathrm{g})\end{array}$ & $\begin{array}{l}\text { The dry weight } \\
\text { of seed per ha } \\
\text { (ton) }\end{array}$ \\
\hline \multicolumn{6}{|l|}{ Bamboo Biochar (B) } \\
\hline $0 \mathrm{tha}^{-1}(\mathrm{~B} 0)$ & $283.61 \mathrm{~b}$ & $283.61 \mathrm{~b}$ & $71.80 \mathrm{c}$ & $24.83 \mathrm{c}$ & $6.12 \mathrm{c}$ \\
\hline $5 \mathrm{tha}^{-1}$ (B1) & $287.97 \mathrm{~b}$ & $287.97 \mathrm{~b}$ & $74.36 \mathrm{bc}$ & $25.08 \mathrm{bc}$ & $7.16 \mathrm{bc}$ \\
\hline $10 \mathrm{t} \mathrm{ha}^{-1}$ (B2) & $304.97 \mathrm{a}$ & $304.97 \mathrm{a}$ & $81.50 \mathrm{ab}$ & $26.38 \mathrm{ab}$ & $8.12 \mathrm{a}$ \\
\hline $15 \mathrm{tha}^{-1}$ (B3) & $305.58 \mathrm{a}$ & $305.58 \mathrm{a}$ & $85.05 \mathrm{a}$ & $26.63 \mathrm{a}$ & $7.47 \mathrm{ab}$ \\
\hline LSD $5 \%$ & 14.55 & 14.55 & 8.72 & 1.31 & 0.68 \\
\hline \multicolumn{6}{|l|}{$\begin{array}{l}\text { Phonska Fertilizer } \\
\text { (P) }\end{array}$} \\
\hline $0 \mathrm{~kg} \mathrm{ha}^{-1}(\mathrm{P} 0)$ & $281.15 \mathrm{~b}$ & $281.15 \mathrm{~b}$ & $71.51 \mathrm{~b}$ & $24.92 \mathrm{~b}$ & $6.37 \mathrm{~b}$ \\
\hline $300 \mathrm{~kg} \mathrm{ha}^{-1}(\mathrm{P} 1)$ & $309.92 \mathrm{a}$ & $309.92 \mathrm{a}$ & $84.85 \mathrm{a}$ & $26.55 \mathrm{a}$ & $8.07 \mathrm{a}$ \\
\hline LSD 5\% & 10.29 & 10.29 & 6.17 & 0.93 & 0.48 \\
\hline
\end{tabular}

Average values followed by the same letter in the same treatment were not significantly different in the 5\% LSD test.

\subsection{Discussion}

The results of this study showed that the highest dry weight of seeds per hectare was obtained at the treatment of $10 \mathrm{t} \mathrm{ha}^{-1}$ (B2) biochar dose of 8.12 tons, which increased by $32.77 \%$ compared with the treatment without biochar (B0) ie 6.12 tons (Table 2). The high dry weight of seed per hectare in treatment of dose of biochar $10 \mathrm{t} \mathrm{ha}^{-1}$ (B2) was supported by significant correlation in observed variables such as maximum plant height $\left(\mathrm{r}=0.86^{* *}\right)$, maximum leaf number per plant $\left(\mathrm{r}=0.84^{* *}\right)$, total leaf area per plant $\left(\mathrm{r}=0.77^{* *}\right)$, dry weight of 100 seeds per plant $\left(\mathrm{r}=0.81^{* *}\right)$, and dry weight of seed per ha $(\mathrm{r}=$ $\left.1.00^{* *}\right)$.

The result of regression analysis of biochar dose with dry seed weight per ha showed quadratic correlation with regression line equation: $\hat{Y}=6.040+0.3557 \mathrm{X}-0.01703 \mathrm{X}^{2}$ with a coefficient of determination $\left(\mathrm{R}^{2}\right.$ ) equal to $64.20 \%$ (Figure 1 ). From the regression analysis, the optimum dose is 10.44 $\mathrm{t} \mathrm{ha}^{-1}$, with dry seed weight per ha maximum weighing 7.90 ton. Based on the results of regression analysis showed that the dry weight of seeds per hectare higher with increasing the dose of biochar to optimum, then decreased when exceeding the optimum dose.

The high weight of dry seeds per hectare in biochar dose treatment of $10 \mathrm{t} \mathrm{ha}^{-1}$ is due to the biochar 
properties that can improve aeration and soil drainage due to improved soil porosity, soil compaction decreases, nutrient and groundwater retention and soil CEC is increasing. This is in line with the results of research from [6], that biochar treatment of $10 \mathrm{t} \mathrm{ha}^{-1}$ can increase the growth of corn crops.

Biochar application can increase soil $\mathrm{pH}$, increase soil aggregate so as to increase fifth hyphae, increase soil water level, increase soil ability to provide $\mathrm{Ca}, \mathrm{Mg}, \mathrm{P}$ and $\mathrm{K}$, increase soil microbial respiration, increase soil microbial biomass, increase cation exchange capacity, increase yield plants (20$120 \%$ ), and improve the quality of plant products [13].

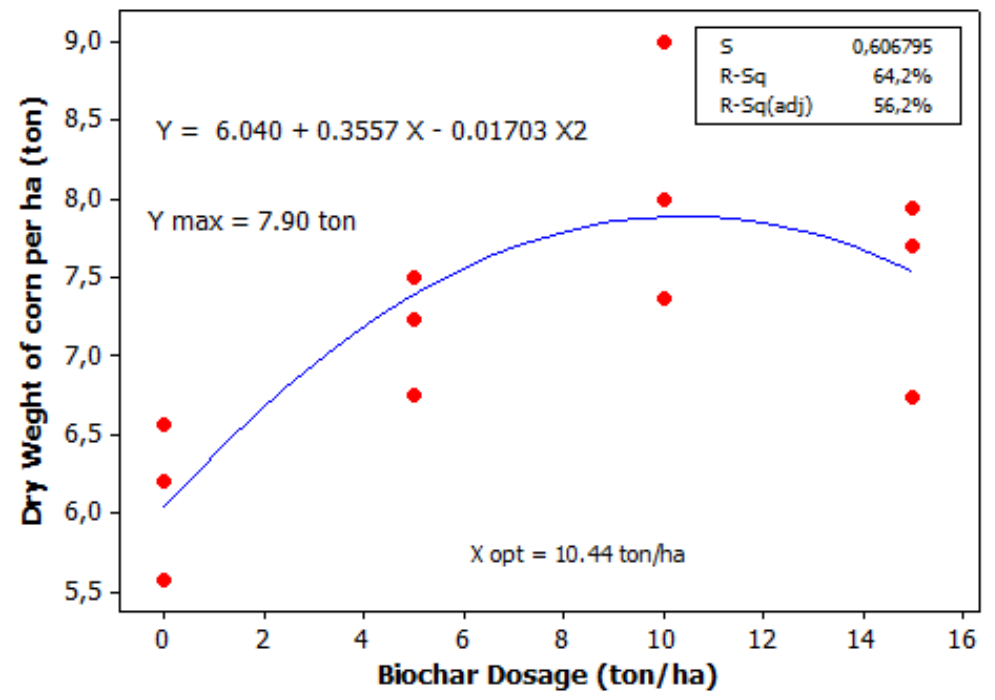

Figure 1

Biochar dosage relationship with dry seed weight per ha

The results showed that the treatment of phonska fertilizer dosage $300 \mathrm{~kg} \mathrm{ha}^{-1}$ (P1) gave the highest dry kiln seed weight of oven per hectare, which was 8.07 tons increased by $26.68 \%$ when compared with without phonska (P0) of 6.37 tons (Table 2).

Nutrient concentration in phonska fertilizer shows that this fertilizer has balanced nutrient availability. The function of compound fertilizers such as this is to accelerate the development of seeds, can be used as fertilizer at the beginning of planting and as fertilizer when the plant enters the generative phase, such as when it begins to bloom or fruiting [14]. Furthermore, [15] suggest that phosphorus (P) nutrients are required throughout the period of growth and the greatest period of use of phosphorus begins during the formation of fruits and seed filling.

\section{Conclusion}

The interaction between the treatment of biochar dose and phonska fertilizer had no significant effect on all observed variables. Biochar treatment significantly influenced most of the observed variables, except on the number of leaves, the age of panicles and hair of cobs was not significant. While treatment of phonska very significant effect on all variables observed.

Treatment of biochar dose of $10 \mathrm{t} \mathrm{ha}^{-1}$ gave the highest dry weight of seed per ha of 8.12 ton 
increased by $32.77 \%$ compared to biochar without 6.12 ton. Treatment of phonska fertilizer dosage of $300 \mathrm{~kg} \mathrm{ha}^{-1}$ gave a dry weight of seed per ha of 8.07 tons increased by $26.68 \%$ compared with phonska without 6.37 tons.

The result of regression analysis of biochar dose with dry seed weight per ha showed quadratic correlation with regression line equation: $\hat{Y}=6.040+0.3557 \mathrm{X}-0.01703 \mathrm{X}^{2}$ with a coefficient of determination $\left(\mathrm{R}^{2}\right)$ equal to $64.20 \%$. As a result of regression analysis obtained optimum dose $10.44 \mathrm{tha}^{-}$ ${ }^{1}$ with dry seed weight per hectare maximum of 7.90 ton.

\section{References}

[1] Aksi Agraris Kanisius (1993). Teknik Bercocok Tanam Jagung. Penerbit Kanisius. Yogyakarta.140 hal.

[2] Adhi, R.K. (2013). Biochar sang pembenah tanah.http://bbppbinuang.info/news23-.html.

[3] Situmeang, Y.P. \& Sudewa, K.A. (2013). Respon Pertumbuhan Vegetatif Tanaman Jagung pada Aplikasi Biochar Limbah Bambu. Prosiding Seminar Nasional. Fakultas Pertanian Universitas Warmadewa, Denpasar.

[4] Artawan, I.K., Situmeang, Y.P., \& Wahyuni, M.D. (2015). The Effect of How The Bamboo Biochar Placement and Dose Towards The Growth and Production of Sweet Corn. Wicaksana, 24(1), 18-28.

[5] Situmeang, Y.P., Sudewa, K.A. Suarta, M., \& Risa, A.A.S. (2016). Biochar and Compost Effect on the Growth and Yield of Sweet Corn. Jurnal Pertanian Gema Agro, XVI (6): 16-19. Fakultas Pertanian Universitas Warmadewa. Denpasar.

[6] Situmeang, Y. P., Adnyana, I. M., Subadiyasa, I. N. N., \& Merit, I. N. (2015). Effect of Dose Biochar Bamboo, Compost, and Phonska on Growth of Maize (Zea mays L.) in Dryland. International Journal on Advanced Science, Engineering and Information Technology, 5(6), 433-439.

[7] Situmeang, Y. P. (2017a). Pemanfaatan Biochar Bambu dalam Meningkatkan Kualitas Tanah dan Hasil Tanaman Jagung (Zea Mays L.) di Lahan Kering (Doctoral dissertation, Universitas Warmadewa).

[8] Situmeang, Y. P. (2017b). Utilization of Biochar, Compost, and Phonska in Improving Corn Results on Dry Land. International Research Journal of Engineering IT and Scientific Research, 3(3): 38-48.

[9] Situmeang, Y.P., Andriani, A.A.S.P.R, Suarta, M., Yuliartini, M.S., \& Resiani, N.M.D. (2017). Aplikasi Biochar, Kompos, dan Phonska Terhadap Kelayakan Hasil Jagung di Lahan Kering. Buletin Teknologi dan Informasi Pertanian, 15(44), 1-7.

[10] Situmeang, Y.P. (2017c). Agronomic Effectiveness of Bamboo Biochar on Corn Cultivation in Dryland. Journal of Biological and Chemical Research, 34(2): 704-712.

[11] Sutedjo, 2010. Pupuk dan Cara Pemupukan. Rineka Cipta. Jakarta

[12] Petrokimia Gresik (2016). Pupuk Phonska. http: //www. Petrokimia-gresik/pupuk/phonska.NPK.

[13] Gani, A. (2009). Potensi Arang Hayati Biochar Sebagai Komponen Teknologi Perbaikan Produktivitas Lahan Pertanian. Iptek Tanaman Pangan Vol. 4 No.1: 33-48

[14] Novizan (2002). Petunjuk Pemupukan Yang Efektif. Agromedia Pustaka. Jakarta.

[15] Suprapto, H.S. \& Marzuki, H.A.R (2002). Bertanam Jagung. Cetakan ke-22. Penebar Swadaya. Jakarta. 48 hal. 